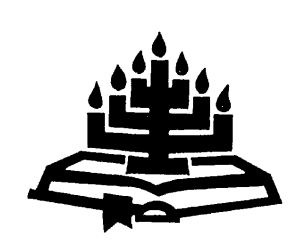

\title{
Tekste, ko-tekste en kon-tekste van die leë graf in die Jesus-tradisie
}

\author{
A.G. van Aarde \\ Fakulteit Teologie \\ Universiteit van Pretoria \\ PRETORIA \\ E-pos: andries.vanaarde@up.ac.za
}

\begin{abstract}
What has been mentioned before in a text may become an indexed feature of the co-text of a later utterance; at the same time, it is part of the situation-specific common background [con-text] knowledge participants may rely on in the production and interpretation of future activities.
\end{abstract}

(Peter Auer, 1996:18-19; kursivisering - AGvA.)

\section{Abstract \\ Texts, co-texts, and con-texts of the empty tomb in the Jesus tradition}

An investigation of texts, co-texts and con-texts of the empty tomb in the Jesus tradition provides a "situation-specific common background knowledge" (Auer, 1996:18-19) from which perspective this article is written. The article aims to argue that the myth behind the empty tomb in the Jesus tradition deploys a trajectory of five links. Its origin, the first of the five links, is to be found in the metaphorical use of the motif of recreation analogous to the foundational narrative in Israel's historical memoirs of God's "creatio ex nihilo". The foundational narrative consists of a collective anthropological facet and an indivdual psychological facet. The anthropological facet is manifested in the memoir of the suppression of Israel as a downtrodden nation. The individual facet pertains to the martyred heroes in Israel's history. In this article the five links of the trajectory are conceptualised in five chronological phases represented by specific textual evidence. They are, firstly, the descent of a corpse into the sheol; secondly, the objectifying of metaphorical language about the resurrection of the dead, which refers to either Israel as a "corporate personality" or individuals; thirdly, the Hellenisation of the resurrection belief-pattern which existed in the Semitic, Eastern-Mediterranean world, in the light of the theology of apotheosis/divinisation and ideas about immortality 
and reincarnation; and fourthly, the empowerment of suffering righteous mortals when participating in the renewed life of resurrected/ascended divine heroes. The fifth phase pertains to the period when the other four phases reached an apogee and resurrection belief served as a kind of coping-healing. The article aims to argue that the hermeneutical significance of the empty tomb in the Jesus tradition is to be found in the third phase. The modes in terms of which Jesus' empty tomb were interpreted by the first "Christ-followers" are to be found in phases four and five.

\section{Opsomming}

\section{Tekste, ko-tekste en kon-tekste van die leë graf in die Jesus- tradisie}

Die artikel is vanuit 'n pragmaties-linguïstieke perspektief geskryf wat 'n onderskeid tref tussen die begrippe "tekste", "kotekste" en "kon-tekste". Hierdie onderskeid verskaf die raamwerk van 'n ondersoek na die tradisie van die leë graf van Jesus, soos blyk uit die vroeg-Christelike literatuur. Die doel van die artikel is om aan te toon dat die mite ten grondslag van die leë-graftradisie ontwikkelingsfases deurloop het. Hierdie ontwikkeling word as 'n trajek met vyf skakels voorgestel. In die eerste skakel word die skeppingsmotief metafories na aanleiding van 'n fundamentele narratief gebruik. Dit herinner aan die oortuiging dat God uit niks geskep het ("creatio ex nihilo"). In antropologiese en psigologiese terme manifesteer hierdie herinnering op 'n metaforiese wyse deur onderskeidelik na Israel as 'n verdrukte nasie en na individuele martelaars in Israel se geskiedenis te verwys. Die skakels van die trajek ontvou chronologies: eerstens die neerdaal van 'n lyk in die doderyk ("sheol"); tweedens die objektivering van metafore wat op Israel as groep en op individuele martelaars betrekking het; derdens die Helleniserende invloed van die "teologie" van apoteose/vergoddeliking, onsterflikheid en reïnkarnasie op Semitiese voorstellings; vierdens die bemagtiging van geregverdigde sterflike lydendes in hulle deelname aan die nuutgemaakte lewe van opgestane verheerlikte helde; en ten slotte dra al genoemde skakels daartoe by dat die opstandingsgeloof as helend ervaar is binne die kultiese konteks van gelowiges wat in reële of simboliese terme rondom die graf van Jesus vergader.

\section{1. 'n Perspektief op 'n plaaslike relevansie}

Twintig jaar gelede, op 7 Mei 1990, het Tjaart van der Walt gesê dat, indien navorsers verplig sou word om die status quo te handhaaf, dit die "skadukant" van navorsing sou wees. Wat vir navorsing goed is, 
is vernuwing, kreatiwiteit, oorspronklikheid en die bereidheid om te waag. Die konteks van hierdie appèl deur Tjaart van der Walt in die negentigerjare van die vorige eeu was die politieke verandering in Suid-Afrika (Van der Walt, 1990). ${ }^{1}$ Dat navorsing nie die bewaring van die status quo as doel mag hê nie, geld egter vir enige institusie - of dit nou ook al die staat of die kerk is.

Dat sekere Christene die tekste in die Nuwe Testament oor Jesus se leë graf as bevestiging van die leerstuk oor Jesus as God sien, is in die kerklike literatuur volop. ${ }^{2}$ Die Nuwe-Testamentiese wetenskap ondersteun egter nie so 'n dogmatiese onderbou van die geloofsartikel dat Jesus God is nie (vgl. Van Aarde, 1998:437-470). Die leë graf in die Jesus-tradisie het 'n ander kommunikatiewe bedoeling. In hierdie artikel word aangetoon dat die "nuwe skepping" een van die sterkste motiewe van die opstandingsgeloof is.

Hierdie motief word ook in 'n ander konteks in die getuienis oor Tjaart van der Walt gevind. In sy positiewe en bevestigende reaksie op die werk van die Waarheids- en Versoeningskommissie (WVK), het Tjaart van der Walt in 1996 'n appèl aan die kerk gerig: "the church must not only prophetically call its members to repentance, but must also accompany them to become new creatures through the grace of God" (Van der Walt aangehaal in Els, 2007:18; beklemtoning - AGvA).

White verwys soos volg na Van der Walt (1992:26) se opmerking oor navorsing se "shadow side":

This connectedness to the state was that it entailed a corresponding connectedness to the status quo and this is not, he felt, good for research, which requires innovation, creativity, originality, risk-taking and not maintenance of the existing order.

2 Vir Karl Barth (1926) was die leerstuk oor die Godheid van Jesus Christus nie op die aanvaarding gebaseer dat Jesus liggaamlik en histories uit die dood opgestaan het nie (vgl. Bultmann, 1964:38-64). Daarvoor het, volgens Barth, geen "wetenskaplike" bewys bestaan nie (vgl. Prenter, 1957:1-88). Barth het wel die opstandingsgeloof as betekenisvol vir Christene gereken, omdat Jesus se opstanding 'n teken is dat God "in Christus" die altyd-lewende God is wat handel (Thiessen, 2009:16-17). Sonder die opstandingsgeloof sal Christene volgens Barth dus sonder toekomshoop wees (vgl. Kantzer, 1958:25-28). Hierteenoor beskryf onder andere Paisly vanuit die perspektief van die Amerikaanse "evangelical" tradisie, sy "sesde rede" in Seven reasons why I believe in the full divinity of Christ soos volg: "I believe then, in the Full Deity of Christ because of the Uncontradictable Actuality of His Resurrection." (Paisly, 2008.) Dit is ook opvallend dat Heyns in sy besinning oor die persoon en werk van Jesus Christus (spesifiek met verwysing na Jesus se verhoging - dit is sy opstanding, hemelvaart, sit aan die regterhand en wederkoms) nie die opstanding sien as bewys van sy Goddelike natuur nie (Heyns, 1978:240-141, 264-268). 
Vir 'n Christen om 'n herskape mens te wees, is as 't ware om opnuut, van Bó, gebore te wees (Joh. 3:3). Hierdie eksistensie is in die opstandingsgeloof gegrond. Hierdie begronding se fundamentele basis gaan terug na die Nuwe-Testamentiese getuienis oor die leë graf in die Jesus-tradisie. Die volhoubaarheid van die appèl van so 'n eksistensie maak die volgehoue hermeneutiese vertolking van die opstandingsgeloof betekenisvol. So 'n hermeneutiese onderneming vereis egter 'n eksegetiese verklaring van die teologiese motief wat grondliggend aan die tradisie oor Jesus se leë graf kan wees.

\section{Die opstandingsgeloof aan die hand van 'n trajekteorie}

Vermes (2008:141-148) wys op ses teorieë wat die betekenis van Jesus se leë graf op grond van die eksegese van die relevante tekste wil verduidelik. Hy wys al ses af. Die eerste teorie is die opinie dat die lyk deur iemand wat Jesus glad nie geken het nie, verwyder is. Tweedens dat die lyk deur sy dissipels gesteel is. Derdens is daar die oortuiging dat die leë graf nooit die graf van Jesus was nie. In die vierde plek word gesê dat Jesus lewendig begrawe is en later die graf verlaat het. Die vyfde teorie is dat Jesus in 'n koma was en uit die koma gekom en Judea verlaat het. Sesdens word geredeneer dat Jesus se verskynings na sy dood 'n geestelike opstanding suggereer en nie 'n liggaamlike opstanding nie. Wat laasgenoemde betref, wys Vermes (2008:147) egter op tekste in die Nuwe Testament wat duidelik sê dat die opgestane Jesus aangeraak is (die ongelowige Tomas, in Joh. 20:27) en dat volgelinge saam met die opgestane Jesus geëet het (die Emmausgangers, in Luk. 24:30; en die dissipels in Joh. 21:13). Hierop reageer Vermes (2008:147) soos volg:

Spiritual resurrection is best associated with visions and appearances. The strictly Jewish bond of spirit and body is better served by the idea of the empty tomb and is no doubt responsible for the introduction of the notions of palpability ... and eating ...

Vergelyk egter die outeur se opmerkings later in die artikel oor die verhaal van die Emmausgangers.

Vermes se ondersoek na die tekstuele getuienis oor Jesus se opstanding herhaal bekende inligting, naamlik dat daar onsekerheid oor die sekwensie van die "gebeure" bestaan, asook onsekerheid oor wat die identiteit van diegene is wat oor die opstanding getuig, sowel as oor die aantal verskynings en die plek waar Jesus sou 
verskyn het. Daar is ook onsekerheid oor weersprekende data wat betrekking het op "voorspellings" (prophecies) dat Jesus sal opstaan en onsekerheid oor die presiese datum wanneer die opgestane Jesus die aarde sou verlaat het (vgl. Vermes, 2008:102-109).

Vermes (2008:151) se eie interpretasie word met behulp van 'n sitaat van die woorde van Winter (1974:208) uitgespel.

Sentence was passed, and [Jesus] was led away. Crucified, dead, and buried, he yet rose in the hearts of his disciples who had loved him and felt he was near. Tried by the world, condemned by authority, buried by the Churches that profess his name, he is rising again, today and tomorrow, in the hearts of men who love him and feel he is near. (Kursivering - AGvA.)

Hoewel ek met Vermes en Winter se manier van verwoording saamstem, word daar in die onderhawige artikel vanuit die perspektief van 'n ander skopus na die vroegste Jesusvolgelinge se opstandingsgeloof gekyk. Verskillende gesigsblikke op vroeg-Christelike tekstuele getuienisse oor Jesus se opstanding is inderdaad moontlik. My uitgangspunt is motief-histories van aard (Motifgeschichte). lemand soos Becker ${ }^{3}$ (2007) volg 'n ander roete wat as 'n "tradisiehistoriese" benadering (Traditionsgeschichte) beskryf kan word. Soos dit tipies binne die histories-kritiese paradigma voorkom, fokus hierdie benadering op die historiese vraag hoe literêre en/of preliterêre tradisies in die vroeë kerk oorgelewer is (Überlieferungsgeschichte).

In vroeëre studies, byvoorbeeld in Fatherless in Galilee: Jesus as child of God (Van Aarde, 2001), is my begrip van Jesus se opstanding taamlik kompak geformuleer. Dit was omdat ek nog nie duidelik genoeg nagedink het oor 'n model aan die hand waarvan ek my verstaan kon verduidelik nie. Onder andere het ek geskryf:

[Jesus] died under uncertain circumstances, but his body was not laid down in a family tomb (Van Aarde, 2001:78).

As with the virginal conception, I do not trace the empty tomb tradition back to the Jesus faction in Jerusalem, but to common Greek thinking that manifested in the stories of the deification of Hercules. (Van Aarde, 2001:112.)

3 Jürgen Becker was professor in Nuwe-Testamentiese Wetenskap aan die Universität Kiel (Duitsland) vanaf 1981-1983. Hy het in 1983 vise-president van die universiteit geword tot en met sy emeritaat in 2000. 
We have seen that the myths of virginal conceptions, ascensions to heaven, and being adopted by the gods are almost recycled ideas ... These stories were not only very familiar in the first-century Greco-Roman world, but also came to mind when (Gentile) philosophers of that period reflected on what Christians said about Jesus, child of God. (Van Aarde, 2001:183.)

Paul developed a theological construct of participation in the risen Christ Jesus. This unity with the cause of Jesus was a faith experience that can be described as an altered state of consciousness because of its spiritual nature ... Because God turns shame into honor, the resurrection faith is, according to Paul, the sign of a new birth, a new start, a new creation ... (Van Aarde, 2001:188).

Uit hierdie vroeëre formulerings, en soos ook in die aanloop van die onderhawige artikel gesê is, is dit duidelik dat ek van oordeel is dat die eerste Jesusvolgelinge se opstandingsgeloof in terme van die begrip nuwe skepping verduidelik kan word. Meer spesifiek ten opsigte van die Evangelie van Johannes, skryf Painter (2008:45): "That an echo of creation should return in the resurrection narrative is not surprising." So 'n eggo is nie net in Johannes aanwesig nie maar, soos De Boer (1998) uitgewys het, ook sentraal in die Pauliniese literatuur. Dit kan onder andere in Paulus (Rom. 5:12-21) se anti-tipologiese gebruik van die begrippe "eerste Adam" en "tweede Adam" gesien word. Dit geld, myns insiens, wyer as net vir Paulus en Johannes.

Die aanwesigheid van die herskeppingsmotief in die opstandingsgeloof word op hierdie stadium van my loopbaan in terme van 'n bepaalde model, voortspruitend uit 'n trajekteorie, uitgewerk. Vanweë die omvang van die tekstuele getuienis gaan ek in hierdie bydrae nie die vertaling van die relevante en geselekteerde tekste bied nie, maar eerstens net wat ek met "trajekteorie" bedoel, en tweedens 'n verduideliking van die pragmaties-linguïstiese begrippe teks, ko-teks en kon-teks. In die derde deel van die artikel sal ek inhoud gee aan my geïdentifiseerde trajek en aan die linguïstiese begrippe. 'n Volgende artikel sal meer op die inhoud van die geselekteerde tekstuele getuienis fokus.

Die feit dat ek 'n ander roete as byvoorbeeld Becker volg, beteken egter nie dat ek van mening is dat myne "beter" of méér "wetenskaplik" is as syne of as dié van ander nie. Ander invalshoeke is byvoorbeeld dié van Nickelsburg (2006) of van Vermes (2008). Ek meen dat ' $n$ navorsingsleemte in bestaande navorsing in terme van 
'n "motief-historiese"-model beskryf en verduidelik kan word. Hoewel ek van 'n geïdentifiseerde navorsingsleemte praat, behoort in gedagte gehou te word dat bestaande navorsing in werklikheid onoorsigtelik geword het as gevolg van die groot omvang van sowel die beskikbare tekstuele getuienisse as die baie gepubliseerde interpretasiemoontlikhede.

Die paradigma waarbinne my model werk, is steeds die "historiese kritiek", maar ek volg nie die tradisionele roetekaart op 'n eksklusiewe wyse deur tekste metodies aan die hand van een historieskritiese metode na 'n ander te ondersoek nie - nie vanaf 'n tekskritiese, 'n tradisie- en vorm-historiese tot 'n redaksie-historiese eksegetiese metode nie.

Becker (2007:1-6) meen dat die tradisies oor die opstanding van Jesus Christus in die Nuwe Testament in terme van twee verskillende lyne ontwikkel en oorgelewer is. Die oudste is dié van Paulus wat 'n ervaring ten grondslag het, naamlik dat hy deur Jesus Christus as apostel geroep is en dat hy 'n visionêre belewenis gehad het wat hy as geestelik (pneumaties) beskryf. Hierdie tradisie is deur 'n outobiografiese genre in briefvorm op 'n belydenisagtige wyse (bekenntnisartig) gekommunikeer. Dit word in 1 Korintiërs 15:1-11 met behulp van 'n lys van ander getuies as legitiem aangebied4 (Becker, 2007:4). Volgens Becker (2007:2) kom 'n tweede tradisie en interpretasie in narratiewe vorm voor, en wel in tekste van die kanonieke evangelies. Waar Paulus se getuienis, volgens Becker, nie na 'n vroeëre literêre basis (Vorform) teruggaan nie die lys van getuies in 1 Korintiërs 15:3-8 het nie as bedoeling om so 'n basis aan te bied nie (vgl. byvoorbeeld Boers, 2006:104-137) het die narratiewe tradisie wel in tweërlei opsig so 'n basis (Fundstelle), eerstens die "engelfanie" (die Auferstehungsbotschaft des Engels im Grabe) en die vroue se besoek aan die graf (der Erzählung vom Grabbesuch der Frauen) in Markus 16:6 en tweedens die "protofanie" aan Petrus (die Erwähnung der Protophanie des Auferstandenen vor Petrus) in Lukas 24:34.

Volgens Becker het albei narratiewe oorlewerings (Überlieferungsstränge) 'n selfstandige tradisiegeskiedenis (selbständige Traditionsströmen). Anders as die Pauliniese getuienis, is die getuies waarop die twee narratiewe oorlewerings bou, aan ons onbekend (Becker,

4 Schüssler Fiorenza (1994:122) verwys na 1 Korintiërs $15: 3-8$ as 'n “... list intended to legitimate male authority". 
2007:3). Waarskynlik is die bronne agter die Pauliniese getuienis produkte van groepskonsensus in gemeentes van die Vroeë Kerk. Hierdie oorlewerings is innerkanonisch. Gesien vanuit die tweebronneteorie, vorm Markus die primêre teks, met Matteus en Lukas wat van Markus afhanklik is, terwyl Johannes saam met drie ander tekste die Markaniese tradisie verder geneem het. Hierdie tekste is naamlik die toegevoegde Markusslot (16:9-20), die Evangelie van Petrus 12:50 en die Epistula Apostolorum 9.5 Volgens Becker $(2007: 3,17,19)$ is sowel Markus as Johannes se lydensvertellings op 'n gemeenskaplike bron gebaseer. Volgens hom word die lydensvertelling deur die vertelling oor die leë graf6 formeel afgesluit.

Soos in die titel van hierdie seksie van die artikel gesien kan word, is dit my bedoeling om die begrip nuwe skepping, as die grondliggende motief van die eerste Jesusvolgelinge, in terme van 'n bepaalde model, naamlik 'n trajekteorie, te verduidelik. In hierdie model word van histories-kritiese insigte gebruik gemaak, omdat ek glo dat die evangelies evolusionêr as vroeg-Christelike volksvertellings op grond van meestal anonieme bronne ontwikkel het. My ondersoek is egter nie net histories nie, maar maak ook van pragmatiese linguïstiek gebruik. Vanuit hierdie perspektief wil ek 'n ondersoek doen na tekste, ko-tekste en kon-tekste van die leë grafbegrip in die Jesus-tradisie. So 'n ondersoek voorsien, soos Auer (1996:18-19) dit noem: 'n "situation-specific common background knowledge", wat die basis vorm van die perspektief waaruit die artikel geskryf is.

Die aanname waaruit die skopus beredeneer word, is dat dit moontlik is om van 'n grondmetafoor agter die idee van 'n leë graf te

$5 \quad$ In die vrouetradisie was Maria van Magdala die eerste om die opgestane Jesus te ervaar (Mark. 16:1, 9; Matt. 28:1; Luk. 24:10; Joh. 20:1; EvPet. 12:50; EpAp. 9 in sowel die Ethiopiese as die Koptiese weergawes). Dit is slegs die Epistula Apostolorum wat nie Maria as eerste in die lys van vroue aandui nie (vgl. Osiek, 1993:97-107). Die "vroue-tradisie" word in die "Petrus-tradisie" (Luk. 24:22-24) sodanig aangebied dat dit die mans ontstel het. Aan die hand van die Pauliniese outobiografiese getuienis, wat op die Petrus-tradisie vir legitimiteit steun, lyk dit myns insiens dat Paulus Petrus-hulle geglo het dat Petrus inderdaad die eerste was wat die opgestane Jesus ervaar het, terwyl Paulus homself in 1 Korintiërs 15:8 as 'n abortus-getuie beskryf (vgl. Van Aarde, 2001:186).

Volgens Becker verwys die leë graf nie na 'n "historisch verifizierbaren Osterereignissen" nie, maar behoort dit gesien te word as 'n vertelling wat literêr gesproke as teken dien om na Jesus se verhoging te wys: "Es verweist nicht extratuell auf ein fixierbares Grab Jesus, sondern is selbst als Erzählung das Zeichen." (Becker, 2007:27.) 
praat. In hierdie artikel word daar nie op die epistemologies vooronderstellings agter die grondmetafoor-begrip of die heuristiese krag wat so 'n begrip in die interpretasie van veral 'n magdom van beskikbare data kan speel, ingegaan nie. ${ }^{7}$ Ek volstaan deur te beklemtoon dat die betrokke grondmetafoor die vorm en inhoud van 'n kosmogoniese mite 8 in beskikbare literatuur aangeneem het. Die aanwending van hierdie mite vertoon ' $n$ historiese ontwikkeling.

Die oorsprong van die mite, die eerste van die vyf skakels, kan gevind word in die metaforiese gebruik van die motief van herskepping/tweede skepping. Hierdie motief word gevind in daardie tekste wat Israel se herinnerings van God se creatio ex nihilo verwoord. Die grondliggende narratief (foundational narrative) het 'n kollektiewe antropologiese en 'n individuele psigologiese kant. Die kollektiewe faset manifesteer in die herinnerings van Israel as onderdrukte nasie. Die individuele faset het op die verhale van Israel se martelare betrekking. Sowel die opstanding van Israel as nasie en die opstanding van individuele martelare, is goddelike dade van herskepping. Herskepping se antoniem word dikwels in metaforiese

$7 \quad$ Vergelyk veral Pepper (1935:365-374) en ook Pepper (1942), Ortner (1973: 1338-1346), Livingstone en Harrison (1981:95-107), Berry (1984:446-448), Sarbin (1986:3-22), Hayes et al. (1988:97-111) en Boe (2005:68-83).

8 Kosmogoniese mites (vgl. Honko, 1984:50-51) het te doen met berigte oor die skepping van die wêreld, die ontstaan van die kosmos en die onderwerping van chaos (Heiler, 1961:283). In hierdie mites is die tydskomponent belangrik. In die algemeen verskil godsdienswetenskaplikes en tekswetenskaplikes oor wat die onderskeid tussen "mitiese tyd" en "historiese tyd" behels (vgl. Otzen, 1980:7). Die Nederlandse godsdienswetenskaplike Gerardus de Leeuw (Sløk, 1960, § 1263-1268) het byvoorbeeld in die dertigerjare die mening uitgespreek dat die tyddimensie in mites óf met Urzeit óf Endzeit te doen het - dus óf vóór (bv. skeppings- en paradysvertellings) óf ná historiese tyd (bv. vertellings oor die nuwe hemel en aarde, m.a.w. herskepppingsmites). Die antropoloog en godsdienswetenskaplike Eliade $(1975 ; 1987)$ het hierdie twee tydsbegrippe, mitiese tyd en historiese tyd, op sintetiese wyse op mekaar laat inwerk. Die mens leef in profane tyd (wat as liniêr voorgestel kan word, omdat dit die lewe chronologies, van geboorte tot dood, omvat - d.w.s. normale historiese tyd). Mense leef terselfdertyd ook in sakrale tyd wat tydens godsdienstige geleenthede in hulle lewe manifesteer. Sakrale tyd is siklies van aard deurdat dit telkens terugkeer en profane tyd deurkruis. Dit het telkens 'n vertrekpunt in die genoemde oertyd (Urzeit), waarna dit die lewensloop van die mens meermale deurkruis. Vanweë die mens se begeerte om "kongeniaal met die gode te wees", manifesteer 'n "eskatologiese begeerte" vir 'n terugkeer na 'n "primordiale situasie" (Endzeit) - waarin die gode en mitiese voorvaders en -moeders teenwoordig is - soms in die mens en in kultiese gemeenskappe. Daarom word skeppings- en paradysmites telkens in mites oor 'n nuwe hemel en aarde herhaal. 
taal uitgedruk met die frase stof tot stof. 'n Mens kan na hierdie soort taal as "teo-antropologiese" taal verwys.

Die teo-antropologie bestaan uit ' $n$ aantal boustene, byvoorbeeld ' $n$ pre-moderne drie-dimensionele kosmologiese teïsme en 'n sosiopsigologiese leefwêreld. In hierdie leefwêreld word die ervaring van die transendente in die alledaagse lewe as gewoon beleef. Hierdie gewoonheid kan egter vinnig afgewissel word met metafisiese ervarings wat as alternerende state van bewussyn beskryf kan word. ${ }^{9}$

In hierdie artikel word die vyf skakels van die trajek voorgestel as vyf chronologiese fases. Vir elkeen van hierdie fases is daar tekste wat daarvan getuig. Die fases is die volgende:

- die neerdaal van 'n lyk (wat bestaan uit liggaam en siel) na die doderyk (sheol), aan die anderkant van die grens van sowel die sosiale menslike wêreld as die simboliese/mitologiese goddelike sfeer;

- om metafore oor die opstanding uit die dode in die alledaagse taal van objekte te verwoord; hierdie opstanding is óf van korporatiewe Israel, óf van 'n individuele martelaar;

- die Hellenisering (Grieks-Romeinse invloed) van die Semitiese opstandingsgeloof; die agtergrond van die Hellenisering is die teologie van apoteose/vergoddeliking en die Griekse idees oor onsterflikheid en reïnkarnasie;

- die bemagtiging van regverdige gelowiges wat ly deur hulle mistiese deelname aan die opgestane helde/gode;

$9 \quad$ Navorsing oor state van bewussyn is omvangryk. Hoewel die aangeleentheid ' $n$ wesenlike komponent van die opstandingsgeloof uitmaak, word in hierdie artikel nie verder daaroor uitgebrei nie. Die volgende opmerking van Wlliam James (1985:388) beklemtoon die kompleksiteit en relevansie van die saak:

[O]ur normal waking consciousness, rational consciousness as we call it, is but one special type of consciousness, whilst all about it, parted from it by the filmiest of screens, there lie potential forms of consciousness entirely different. We may go through life without suspecting their existence; but apply the requisite stimulus, and at a touch they are there in all their completeness, definite types of mentality which probably somewhere have their field of application and adaptation. No account of the universe in its totality can be final which leaves these other forms of consciousness quite disregarded. How to regard them is the question - for they are so discontinuous with ordinary consciousness. Yet they may determine attitudes though they cannot furnish formulas, and open a region though they fail to give a map. At any rate, they forbid a premature closing of our accounts with reality. 
- die opstandingsgeloof wat as "coping-healings" funksioneer wonderwerke met 'n helende uitwerking.

Die agtergrond hiervan is die apokaliptiek/millennialisme. In so 'n leefwêreld bevind regverdige mense hulle vasgevang in 'n spiraal van stryd en verwerping. Die doel met hierdie artikel is om te illustreer dat die fokus van die tradisie van die leë graf van Jesus in die derde skakel gevind kan word. Die wyse waarop die eerste Christene Jesus se leë graf geïnterpreteer het, het op fases vier en vyf betrekking.

Tekste kan geselekteer word om as getuienis van die vyf skakels te dien. Wanneer 'n groot aantal tekste met mekaar in verband gebring word om aan te toon dat ' $n$ goue draad hulle verbind, bestaan daar egter die gevaar van parallellomania (Sandmel, 1962:1-13). Om hierdie gevaar te vermy, is die trajekteorie deur Koester en Robinson (1971) in hulle boek Trajectories through early Christianity ontwikkel. Parafraserend in my eie woorde word die volgende verhelderende opmerkings van Robinson (1971:10-11) in die inleiding van hierdie boek gevind.

$\mathrm{Na}$ twee eeue van kritiese historiografie het ons, ten spyte van al die beperkings wat eie is aan die eie-aard van geskiedskrywing, tot 'n belangrike bevinding gekom. Die geskiedenis van die vroeë Christene vertoon sonder twyfel 'n ontwikkeling ten opsigte van teologiese insigte. Jesus het nie soos Paulus gedink nie. Hoewel daar raakpunte tussen Paulus en Markus is, is daar ook verskille in hulle teologieë. Origenes se oortuigings verteenwoordig ' $n$ latere fase in die trajek van die vroeë kerkgeskiedenis. Daarna volg die teologie van Augustinus en Atanasius. Hierdie diversiteit is egter nie net 'n kwessie dat pluraliteit 'n werklikheid in die lewe van die vroeë Christene was nie. Wanneer gemelde teoloë se teologieë noukeurig nagegaan word, word dit duidelik dat hulle nie net individue was wat van mekaar verskil het nie. Hulle individuele oortuigings verteenwoordig momente in stromings wat sin maak, omdat dit in ' $n$ bepaalde tyd van die geskiedenis van die vroeë kerk neergeskryf is. Die ontwikkeling in teologiese insigte vanaf een na ' $n$ volgende fase kan slegs noukeuriger beskryf en verklaar word indien die geskiedskrywing die resultaat van kritiese historiese navorsing is. Dit is daarom nodig dat die tekste van vroeë teoloë - insluitende dié wat draers van die Jesustradisie was - gedateer en gestratifiseer word, hoe problematies so 'n onderneming ook mag wees. Die daarstelling van so 'n sekwensie van tekste, oortuigings en teologieë word 'n trajek genoem. 
In hierdie artikel pas ek so 'n trajekteorie toe om my in staat te stel om die groot aantal tekste oor die opstandingsgeloof in terme van 'n model te verklaar. Daar is egter, epistemologies gesien, 'n gevaar in so 'n onderneming. Die daarstelling van 'n trajek moet nie die resultaat determineer in die vooronderstelde epistemologie ten grondslag van die historiese argumentvoering nie. 'n Vooronderstelde epistomologie kan byvoorbeeld 'n deduktiewe hipotese op 'n positiwistiese wyse wees. Robinson (1971:14) was ook van so 'n historiese-positivisme bewus. Een manier om dit teë te werk, is om in ag te neem dat 'n bepaalde teks en die resepsie van daardie teks nie altyd slegs één ding in al die kontekste waar dit aangetref word, beteken nie. In hierdie studie is dit belangrik dat 'n bepaalde getuienis oor die opstandingsgeloof in een konteks in die vorm van beeldspraak kan voorkom, maar in 'n ander konteks kan die metafoor wat voorheen gebruik is, op 'n objektiverende wyse verwoord word. So byvoorbeeld kan doodsbeendere (d.w.s. 'n geraamte) metafories na Israel in ballingskap verwys, en later kan hierdie tekstuele getuienis op 'n objektiewe wyse na martelare in Israel se reële geskiedenis verwys. So ook verwys die objek "dou" in die vorm van beeldspraak op een plek na 'n transendente krag wat aan dooie stof lewe gee en op 'n ander plek word hierdie metaforiese gebruik weer geobjektiveer deurdat die "krag" op die Gees van God betrekking het. Hierdie veranderings in referensiële betekenis verwoord Robinson (1971:14) soos volg:

At one stage of a movement a document may function in a specific way, have a certain meaning or influence on the movement; at a subsequent stage on the trajectory that document, unaltered, may function or cut in a different way, may mean in effect something different, may influence the movement differently.

Teen hierdie agtergrond word positivisme in hierdie artikel verder teëgewerk deur insigte aan die pragmatiese linguïstiek te ontleen. Op grond van hierdie insigte word, benewens die teks self, ook onderskei tussen ko-teks en kon-teks. Porter (1997:195) stel dit soos volg:

A discourse, then, pertains to the communicative levels and all of those in between. These levels of discourse may be categorized under two headings: co-text and context. Co-text refers to linguistic units that are part of a discourse and, more specifically, linguistic units that surround a particular point in the discourse. Context refers to extralinguistic factors that influence discourse production, and interpretation, and it may be broadly 
categorized in terms of the context of situation, that is, the immediate historical situation in which a discourse occurs. 10

Wanneer bepaalde tekstuele getuienis ten opsigte van die opstandingsgeloof geselekteer word om die gemelde vyf fases te illustreer maar "parallellomania" voorkom wil word, kan die tekste in eie reg bestudeer word deur elkeen se teks van die ko-teks en die kon-teks te onderskei.

Teks is die bymekaarkom van woorde in sinne en paragrawe. Die betekenis van teks word deur die ondersoek na die semantiek van woorde, die relasie van woord in sinne en sinne binne paragrawe vasgestel.

Ko-teks is wanneer die bymekaarkom van woorde, sinne en paragrawe as 'n eenheid bestudeer word. Hier is leesstrategieë soos die resepsie-estetika van nut. Wat vroeër in 'n teks as 'n eenheid gesê is, skep die verwysingsraamwerk om wat later gesê word, in reliëf te plaas. Wat tussen die reëls gesê word - wat by wyse van bewuste of onbewuste gapings deur outeurs geskep of gelaat is - kan met behulp van die fokus op ko-teks verklaar word. Wat die Nuwe Testament betref, is insigte uit die narratiewe kritiek bruikbaar om verteltekste as 'n geheel te ondersoek. Insigte uit die retoriese kritiek is bruikbaar om argumente in epistolografiese literatuur te verstaan.

Ko-teks en teks is egter nie genoegsaam vir 'n meer omvattende interpretasie nie. Dit is nodig dat semantiek met semiotiek aangevul moet word. Woorde in tekste en relasies van sinne in ko-tekste verwys ook na gegewens buite 'n bepaalde teks. Kon-teks is daarom ook belangrik. Insig in die kon-teks word deur kennis van die leefwêreld van outeurs en die ontvangers van hulle tekste verkry. Reed (1997:216) stel dit soos volg:

Essentially, what this implies is that language comes to life only when functioning in some environment ... The 'context of situation' does not refer all the bits and pieces of the material environment ... It refers to those features which are relevant to the speech that is taking place.

Kon-teks verwys dus na "situation-specific common background knowledge" (Auer, 1996:18-19). 
Wat die fases in die geïdentifiseerde trajek met betrekking tot die opstandingsgeloof betref, sal daar in hierdie artikel, benewens die tekste wat verteenwoordigend van die onderskeie vyf skakels in die trajek is, ook kennis geneem word van ko-tekste en hulle kon-tekste.

\section{Die eerste skakel: vasgevang in die strik van die doderyk}

My opskrif van die "eerste skakel" is aan Psalm 18:4-6 ontleen. Digterlik word vertel dat die dooie neergevel is deur 'n vyand wat die gelowige soos 'n dier afmaai. In mitologiese taal word die gevangenis as "golwe van chaos" voorgestel (vgl. Van Uchelen, 1971:19). Dit is soos Jona wat met sy wens om dood te gaan nie eintlik daaraan gedink het dat hy aleeds drie dae in die doderyk was toe golf na golf oor hom gespoel het en toe hy in die vis se maag, van God en die tempel afgegrendel was nie (Jona $2: 2-4 ; 4: 8$ ). Op metaforiese wyse, soos die skadu van die wonderboom (Jona $4: 1-11$ ) lewe bied téén die moordende son en wind, red die Skeppergod (Human, 2004: 233) die stad Nineve (kollektief) wat in sak en as (Siebert-Hommes, 2003:285) is, asook Jona (individueel) vanuit die put van die dood (Keel, 1972:62) - uit die sheol (Jona 2:6). Human (2004:231) beskryf die metafoor, verwysende na die sheol en die onwerklikheid van opstanding uit die dood (Landes, 1967:446), na God se herskeppingskrag.

Die 'drie dae en drie nagte' in die vis se ingewande bevat ... 'n mitologiese sinspeling. Dit antisipeer dat Jona se dood onafwendbaar en permanent is. In die antieke Nabye-Ooste het die voorstelling bestaan dat die dood van 'n liggaam na 'n drie dae periode permanent is (1 Sam. 30:12). Hoop op herlewing is hierna onmoontlik ... In die Babiloniese mitologie het die uitdrukking die tydperk aangedui wat dit 'n reis van die land van lewende na die land van die dood, Sheol, neem. Hiervan is Inanna/lshtar se reis na die onderwêreld 'n voorbeeld.

In hierdie vroegste fase word die opstandingsgeloof verwoord in terme van die begrip doderyk (sheol). Hierdie fase verwys na die terminering van skepping en dit het betrekking op die neerdaal van 'n lyk (wat bestaan uit liggaam en siel) na die doderyk (sheol). In sy kommentaar op Genesis 1, verwys Van Selms (1967:19) op 'n aangrypende wyse na skepping.

Tussen eeuwigheid en geschiedenis staat de schepping. Men kan haar niet als gewone geschiedenis bescrijven, want de schepping is de vooronderstelling van de geschiedenis. De schepping moet plaastvinden, voor de geschiedenis beginnen 
kan ... de scrijver bedoelde dat aan Gods scheppingswerk een chaos voorafging, die niet uit Gods schepperhand voortgekomen was. Scheppen is dan uitsluitend ordenen, niet de stap van niets tot iets.

Sterwe verteenwoordig dus die "stap van iets tot niets". Die sheol is met ander woorde aan die ander kant van die grens van sowel die sosiale menslike wêreld as die simboliese/mitologiese goddelike sfeer. Uit die baie beskikbare tekste wat van hierdie eerste fase verteenwoordigend is, dien Job 14 en Prediker 3:21 as voorbeeld. Laasgenoemde teks, volgens Crenshaw (2006:69-70), net soos Job 14:7-12, "may consitute his rejection of belief in immortality".

Wat Job 14 as teks betref, som Rowley (1970:127) die ko-teks ten opsigte van outeursintensie soos volg op:

A lopped tree may grow again, but death is final. He then wishes that God would give him temporary refuge in Sheol until his anger was overpast, but ends, as he [the author] has done before, by reflecting on the cheerlessness of the prospect of Sheol.

Job en Qohelet (Prediker) is in hierdie verband "sielsgenote" (Crenshaw, 2006:70; vgl. ook 1995:573-585). Wat die ko-teks van Job betref, wys Vermes (2008:5) ook op die verband tussen Job 7:9 en Job 14:14. Die konteks van hierdie tekste is die oos-Mediterreense siening dat die sheol 'n onoorbrugbare grens vorm tussen hulle wat dood is en hulle wat lewendig is, asook tussen die dooies en God. Daar is getuienis dat mense op grond van 'n alternatiewe staat van bewussyn (vgl. Walsh, 2007:71-84) in hulle gewone lewe gemeen het om op 'n mistieke wyse met die hulp van dodebesweersters/ders kontak te maak met diegene in die sheol (bv. 1 Sam. 28). Tog is die onoorbrugbare grens nooit oorgesteek nie. Selfs in die laat fase van die geskiedenis van Israel word hierdie kon-teks steeds aangetref. Hiervan is Jesus ben Sirag 17:27-28 'n voorbeeld waar gestel word dat die dooies in die sheol God nie kan prys nie (Harrington, 2005:42). Jesaja 38:11, 18-19 vorm in 'n sekere sin 'n oorgang tussen die eerste en die tweede fase. Koning Hiskia sing 'n loflied tot God wat hom van sy dodelike siekte genees het en betuig, soos ook deur Jesus ben Sirag (van Jerusalem) gestel, dat indien hy sou sterf, hy God en die mense nie meer sou sien nie. Immers, in die sheol kan niemand God meer prys nie. Net dié wat lewe, kan God loof (vgl. Crenshaw, 2006:73-74, nota 8). Dit bevestig dat die skakels in die trajek soos 'n spiraal aan mekaar gebind is. 


\section{Die tweede skakel: dou gee lewe aan stof}

In die tweede fase word die skeppings- en herskeppingsmotief gesuggereer. Jesaja 26:19 is, net soos die ko-teks van Jesaja 2427, duidelik deel van die tweede fase. Nickelsburg ( 2006:30-32, 38, 187 ) toon die rol van stof as metafoor treffend in hierdie teks aan. Eksegete aanvaar in die algemeen dat die dooie hier na Israel as 'n korporatiewe persoonlikheid verwys (Snijders, 1969:264), soos ook in Esegiël 37 (die opstaan van doodsbeendere) (Nickelsburg, 2006: 31).

In Jesaja 26:19 is die gebruik van die doumetafoor kenmerkend van die teks (vgl. Wright, 2003:117, nota 140). Soos die dabar-motief (skepping deur 'n "woord" - vgl. Heb. 11:3) in Genesis, verwoord dou die krag van regenerasie. Hier word metafore dus as objekte voorgestel, verwysende na Israel as nasie.11 Die ko-teks van hierdie tipe teks is die aanvangsperiode van die apokaliptiek as 'n millennialistiese beweging. Ander tekste vanuit hierdie fase is onder andere Daniël 12, 1 Henog 14:8, 2 Henog 1:18 en 2 Makkabeërs 7:1-42. Onder die Qumran-tekste is onder andere Pseudo-Esegiël (4Q385 fragment 2), Hodayot $\left(1 \mathrm{QH}^{\mathrm{a} ;} 16.5-6\right.$, asook $1 \mathrm{QH}^{\mathrm{a}} 10$; vgl. Charlesworth, 2006:4-5), of die Testament van Juda (vgl. Nickelsburg, 2006:49).12 Die kon-teks van hierdie tekste illustreer hoe die kollek-

11 Jare later as deel van die resepsie van die Rabbynse tradisie eggo Eleasar B. Kalir se doulied steeds in die jaar 700 n.C. voort (Snijders, 1969:265; vertaling in Afrikaans uit Nederlands - AGvA):

Ons God en God van ons oupa's en ouma's, gee dou ter wille van die aarde wat $U$ s'n is, en omskep ons in 'n seën vir ander wat vir $U$ sal verbly. Skenk koring en mos in oorvloed, en bou Jerusalem weer op deur dou!

Die stad wat as 'n verlate hut oorgebly het, omskep die stad in 'n kroon in $\mathrm{u}$ hand - deur dou!

Dou sprei uit oor heel geseënde Israel.

Dou versadig ons met die kostelikheid uit die hemel, omdat lig uit duisternis straal - deur dou!

Israel, bevry uit hulle kettings, vind by $U$ genade. Dan sal ons liedere aanhef en jubelend sing - oor dou!

Vul ons voorraadskure met oorvloed - voortgekom uit dou! Hernu ons dae soos vroeër. Laat ons 'n lushof wees - deurdrenk deur dou!

12 Schutte (2008:1077) is korrek om in sy kritiese "review article" van Nickelsburg se verwerkte en uitgebreide boek oor die opstandingsgeloof in die antieke wêreld van Bybelse getuienisse, met die metafoor doodsbeendere 'n verwysing na die realiteit dat mense inderdaad dood was, te veronderstel. Ek meen egter dat Esegiël 37 gestratifiseer behoort te word as steeds volledig deel van die beginfase van die tweede skakel in die trajek oor hoe die opstandingsgeloof 
tiewe gebruik van Israel as nasie net so oorgedra word na individuele regverdiges wat as gelowige martelare bereid was om vir hulle geloof in God te sterf. Die kon-teks is dus die marginalisasie van mense in die geskiedenis (vgl. Crossan, 2003:29-57). Ander tekste wat hierdie fase van die opstandingsgeloof treffend illustreer, is Pseudo-Esegiël se kommentaar op Esegiël 37, asook 1 Henog op Daniël.

Deur die eerste skakel in die trajek van die tweede te onderskei, word eksegete gehelp in die moeilike keuse om te besluit of Daniël 12 chronologies ná Jesaja 26:19 ontstaan het. Die objektivering van 'n metafoor suggereer dat Jesaja 26:19 as basisteks vir tekste soos Daniël, 2 Makkabeërs en die betrokke Qumran-tekste gedien het.

\section{Die derde skakel: "vlees en bloed kan nie die koninkryk van God beërwe nie"}

Net soos die politieke geskiedenis sedert Alexander die Grote, verteenwoordig die derde skakel in die trajek 'n fase waar tekste getuienis word van sinkretistiese tendense. Dit is die periode van platonisering (Roukema, 1998:135) en hellenisering (Hengel, 1974, 1989). ${ }^{13}$ Dit geld ook vir die tyd van die Romeinse Imperium. $\mathrm{Na}$ aanleiding van die beslissende invloed van Hengel (1980:53), stel Grabbe (2002:51): "Hellenization as a process - not just a static

histories ontwikkel het. Tekste wat 'n soort resepsie van Jesaja 26:19 óf Esegiël 37 verteenwoordig, vorm as 't ware alreeds die skarnier na die tekstuele getuienis wat in die derde fase tuishoort soos byvoorbeeld Daniël 12, 1 Henog 14:8, 2 Henog 1:18, 2 Makkabeërs 7:1-42 en die Qumran-tekste (o.a. PseudoEsegiël 4Q385 fragment 2; Hodayot $1 \mathrm{QH}^{\mathrm{a}}$ 16.5-6; asook $1 \mathrm{QH}^{\mathrm{a}} 10$; vgl. Charlesworth, 2006:4-5), of die Testament van Juda (vgl. Nickelsburg 2006:49). Laasgenoemde tekste behoort nie sonder meer sinchronies op dieselfde stratifikasievlak as Jesaja 24-27 of Esegiël 37 geïnterpreteer te word nie.

13 Grabbe (2002:52-66) wys op die beslissende impak wat Hengel op die studie van die $\mathrm{Ou}$ en die Nuwe Testament en op tussentestamentêre dokumente gehad het.

\footnotetext{
Hengel's dictum is becoming more and more accepted: one can no longer talk of Judaism versus Hellenism nor of Palestinian versus Hellenistic Judaism. To do so is to create an artificial binary opposition and to reduce an enormously complex picture to stark, unshaded black and white. It is also to treat a lengthy process as if it were a single undifferented event - as if conception, pregnancy, birth, childhood, and adulthood could be simultaneous ... A more thorough 'Hellenization', which also included the lower classes, only became a complete reality in Syria and Palestine under the protection of Rome ... It was Rome which first helped 'Hellenism' to its real victory in the East.
} 
culture - continued with the coming of the Romans and the growth of their empire." Grieks het inderdaad die Israelse literatuur wyd beïnvloed. Dit sluit egter nie net Grieks-Semitiese werke soos dié van Filo in nie, maar ook Hebreeuse (o.a. Qohelet) en Aramese geskrifte (o.a. sekere Qumran-dokumente; ten spyte van die kritiek teen Hengel se impak deur Feldman, 1986:83-111; 1997:371-382; vgl. Borgen, 1994:30-59), asook 1 Henog en die Testamente van die Twaalf Patriarge.

In die wes-Mediterreense sosiale wêreld het die Platoniese ideologie van skeiding tussen siel en liggaam (bv. Plato, [1900] 1967a:70c-d, 72a; 1.57a-118a), asook die moontlikheid van die onsterflikheid van die siel, ' $n$ besondere invloed op die Semitiese oos-Mediterreense leefwêreld uitgeoefen. Plato se teologie het begin oorheers. Net soos Plato 'n skeiding tussen die idees van gode en hulle mites en dié van mense en hulle heroïese lewensverhale maak, maak hy ook skeiding tussen liggaam en siel - maar 'n siel wat kan reïnkarneer in 'n volgende liggaam. Helde kan gode word selfs as hulle liggame ontbind, verbrand of in die see verdwyn. Die voorwaarde is dat hulle as helde in die kring van die aristokrasie en deur gode erken word, en óf met hulle geboorte, óf met hulle dood as gode of demi-gode herken word.14 'n Mens vind dus in die tekste vanuit hierdie konteks 'n ooreenkoms tussen goddelike verwekkings en opstandings wat tot vergoddeliking lei (vgl. veral die teksversameling deur Dungan \& Cartlidge, 1974). Wat die leë-graftradisie betref, is werk van Diodorus van Sicilië, die "teoloog" van Alexandrië, Diodori Bibliotheca Historica, waarskynlik een van die bekendste tekstuele getuienis in hierdie verband (Diodorus Siculus, Biblos Tetartē, 4, 6.1-4, aangehaal in Oldfather, 1935). In Diodorus se tekste dui die ko-teks van narratiewe byvoorbeeld op die heroïese verhaal van Herakles (Griekse spelling) en sy deïfikasie op grond van 'n leë graftradisie, terwyl Seneca satiries spot oor die deiffikasie van keiser Claudius op grond van sy ascensus na die sfeer van die gode. Volgens Seneca behoort dit eerder 'n descensus na Hades te wees, want Claudius het nie die waarde van die vergoddelikke keiser Augustus (divus Au-

14 In die negende boek van Plato se Leges (Plato, [1900] 1967b:11.624a-969d:90) skryf Plato dat onsterflikheid dié hoogste waarde (aretē) bo mooiheid, krag en verstand is - dié waarde wat gode en helde die menslike kondisie laat transendeer, omdat hierdie waarde hulle van gewone mense onderskei (Vernant, 1995:263; vgl onder andere ook Steven, 1933:149-155). Dit is daarom verstaanbaar waarom die Epikurese en Stoïsynse filosowe in die Areopagus in Athene die Lukaniese Paulus bespotlik maak as hy oor Jesus van Nasaret se opstanding uit die dood getuig (Hand. 17:16-34). 
gustus) nie (Seneca, Apocolocyntosis 10.1; vgl. Ball, 1902:203; Van Aarde, 2001:165-125; 1997:150-172; 2000:188-201). Diodorus is 'n voor Nuwe-Testamentiese skrywer (1e eeu VHJ). ${ }^{15}$ Lucius Annaeus Seneca, wat in sy werke Hercules Furens and Hercules Oetaeus, die verhale van Hercules (Latynse spelling) se goddelike verwekking en apoteose by opstanding vertel, is egter kontemporêr in vergelyking met die skrywers van die Nuwe Testament.16

Paulus, die belangrikste kontemporêre Nuwe-Testamentiese skrywer van hierdie fase, sluit aan die een kant by die oos-Mediterreense leefwêreld aan waar metafore geobjektiveer word. Aan die ander kant is sy leefwêreld ook deur die wes-Mediterreense platonisering en hellenisering beïnvloed. Op grond van Filippense 3:12-4:1 is dit vir Paulus duidelik dat Jesus die metaforiese wedloop gewen het om die oorwinning oor die dood te behaal (vgl. veral die eksegese van Boers, 2006:104-137). In 1 Korintiërs 15 is die sinkretiserende tendens van ' $n$ vermenging van die Grieks-Romeinse leefwêreld met die Semitiese nog meer opvallend.

Vir Paulus dien 1 Korintiërs 15:3-8 as 'n objektiewe bewys dat ander gelowiges (insluitende Paulus self as die "laaste/geringste" geloofwaardige getuie) Jesus wat dood was en weer lewe, gesien het. Hierdie getuienisse dien as motivering vir hom om die opstandingsgeloof in terme van 'n creatio ex nihilo te verwoord. Om in ons naAufklärungsera Paulus se "bewysvoering" as grond vir historisiteit en faktisiteit te reken, is om sy premoderne retoriek nie te verreken nie. Paulus verwys na sy getuies as "objektiewe bewys" in epideiktiese retoriese sin en het nie juridies argumente oor feite van die verlede of deliberatief argumente oor waarskynlikhede in die toekoms in die

15 Vergelyk Diodorus Siculus (4.38.3-5). Vergelyk ook Diodorus se tekste oor Herakles (Dungan \& Cartlidge, 1974:347-353). Osiek (1993:102) het die parallel tussen Jesus se leë graf en dié van Herakles soos volg beskryf:

Most texts [about the relationship between resurrection beliefs and resuscitated body in the first-century Mediterranean world] are ambiguous, but some ... seem to suggest a close connection, as does one Greco-Roman apotheosis story, that of Hercules by the firstcentury BCE, historian, Diodorus Siculus. Hercules mounts the funeral pyre, which is consumed by a bolt of lightning. Those who came afterwards to gather the remains find no bones, and conclude that Hercules has been translated to the realm of the gods. Paul's analogies to seed sown and astral bodies in 1 Corinthians 15:35-44 are open to a variety of interpretations, but it does seem as if some continuity with the physical is supposed in the pneumatic transformation.

16 Wat Seneca betref, vergelyk ook Dio Cassius, Historiae Romanae 60.35.3-5, aangehaal in Eden (1984:73; vgl. Ball, 1902:203). 
oog nie (vgl. Van Aarde, 2004:512). Met behulp van 'n epideiktiese (ofte wel paradigmatiese) retoriek wil hy sy lesers tot instemming bring met die waarde (aretē) dat die geloof in die opstanding 'n etiek van konstante en onvermoeide arbeid in gehoorsaamheid aan Jesus Christus as heerser (kurios) tot gevolg het, bedoelende die uitleef van God se geregtigheid (dikaiosunē) - vergelyk 1 Korintiërs 15:58 as sluitende argument (vgl. Wright \& Crossan, 2006:42-47, wat ten spyte van hulle onderlinge verskille hieroor saamstem).

Hierdie hoogtepunt van die groot diskoers van Paulus oor die opstanding kan soos volg vertaal word:

Die resultaat van my argument is dus, my geliefde broers [en susters], wees konstant, sonder om van die spoor gebring te word, altyd meer fluks in julle werk vir die Heerser van julle lewe, terwyl julle bewus bly dat julle nie tevergeefs vir die Here werk nie. (1 Kor. 15:58; vertaling uit Grieks - AGvA.)

Hierdie hoogtepunt is voorafgegaan deur Paulus se redenering in 1 Korintiërs 15:35-49 aan die hand van die metafoor van 'n koringkorrel wat in die aarde sterf en daardeur lewe aan iets méér heerlikheid gee sodat 'n geestelike mens (sōma pneumatikon) as die transendering van die vleeslike/verganklike/sarkikos mens (sōma psuchikon) gesien kan word. Hierdie is 'n duidelike voorbeeld van hoe 'n metafoor sonder meer in dieselfde ko-teks objektiverend geïnterpreteer is.

In die laaste geskrewe teks wat ons van Paulus het, te wete die brief aan die Romeine, blyk hoe hy in die indikatiewe (Rom. 1-8) sowel as die imperatiewe deel (Rom. 12-15) op dieselfde waarde klem lê. Die neerslag van 'n Grieks-Romeinse teologie van apoteose in Romeine 1:3-417 vorm 'n duidelike ooreenkoms met die teologie van wat onder andere by Seneca en Diodorus Siculus oor die Herakles-tradisie aangetref word. Op die berg Oïte het Herakles uit eie wil sy dood tegemoet gegaan. Die brandstapel was sy graf. Toe geen reste van sy liggaam gevind is nie, is Herakles as die seun van Zeus verklaar op grond van sy verhoging na die sfeer van die gode (vir die tekste

Die evangelie gaan oor God se Seun, wat in terme van verganklike menswees (kata sarka), uit die saad van Dawid gebore is. Tegelykertyd is dit vooraf deur God beskik dat hy God se Seun is - en dit op grond van God se krag in terme van die gees van heiligheid (kata pneuma agiōsunēs) as gevolg van sy opstanding uit die dood - Jesus Christus, óns Kurios. (Vertaling uit Grieks - AGvA.) 
vgl. onder andere Dungan \& Cartlidge, 1974:352-353). 'n Raakpunt tussen die wes- en die oos-Mediterreense kontekste ten opsigte van die opstandingsgeloof is in die Pauliniese korpus opvallend.

\section{Die vierde skakel: die appèl om uit te hou en aan te hou}

Die vierde skakel in die trajek is steeds heg met die derde ineengeskakel. 1 Tessalonisense 4:13-18 en Markus 12:1-8 is illustrasies van die vierde skakel. By Paulus 18 word gelowiges in die aangesig van die dood opgeroep om mekaar wedersyds te bemoedig (vgl. ook 1 Tess. 5:11). By Markus, in die vorm van 'n gelykenis van Jesus oor die werkers in die wingerd, word gelowiges opgeroep om nie te vrees vir antagonisme wat die dood tot gevolg kan hê nie. Die konteks van die vierde skakel is dat op grond van die kernmotief van vindikasie (die basis van die teologie van apoteose), die verhoogde/ opgestane goddelike held die krag van die bemagtiging van ander treurendes (Paulus) en vresendes (Markus) word.

In hierdie konteks is dit duidelik hoe Griekse skrywers soos Hesiodus (1970; d.i. 8/7 VHJ) en Josefus (1955; d.i. 1 AE) reeds 'n bepaalde konteks help skep het. Daarom kon Markus en Paulus albei op 'n paradoksale wyse sterwe en opstanding as twee kante van dieselfde saak sien. Josefus (1955; De bello Judaico 2.163 en Antiquitates Judaicae 18.14) praat van die psuche van die regverdiges wat by die dood getransformeer word (metempsychosis) in 'n andersoortige sōma - dit wil sê "revivikasie", terwyl die psuche van die goddelose aan onophoudelike lyding uitgelewer is (vgl. Elledge, 2006:37-30). Hesiodus (1970:166-173) het ook verwysings na 'n sogenaamde postmortem vindikasie op die eiland van die gelukkiges ('n begrip wat reeds by Plato en Homeros! aangetref word) teenoor lyding en straf wat die lot van die ongelukkiges is (vgl. Wright, 2003:50, nota 100). In sy verwysing na Hesiodus (1970:287-292) se invloed op die leefwêreld, praat Nickelsburg (2006:203, nota 121) van "the biblical two-ways material".

181 Tessalonisense is Paulus se eerste geskrif wat ons tot ons beskikking het. Ten opsigte van die apokaliptiese/millennialistiese vergeldingsmotief verskil dit sterk van sy latere geskrif, veral sy Romeine-brief as sy laaste geskrif (vgl. Van Aarde, 2008:1677-1685). Tog is die motief dat Jesus Christus "vir ander" ly en sterf, reeds in 1 Tessalonisense gesuggereer (vgl. 1 Tess. 1:6) en dit word deurgaans in sy ander geskrifte aangetref (Rom. 5:6; 8:32; 14:15; 1 Kor. 1:13; 15:3, 29; 2 Kor. 1:6; 5:14, 15, 21; Gal. 1:4; 2;20; Fil. 1:4). 
Deelneming deur die treurendes en die vresendes lei tot die paradoks van gebind wees aan die sarks, maar tegelykertyd deur die pneuma beheers te word, slaaf van die verganklike skepping te wees en tegelykertyd as slaaf van God (en/of Christus) herskep te wees.

\section{Die vyfde skakel: 'n grafkultus}

In die vyfde fase het die trajek die sirkel voltooi. Die konteks is steeds die stryd tussen goed en kwaad, tussen regverdiges en goddeloses en tussen martelaarskap en weergeboorte. Tekste wat die vyfde fase illustreer, word in die laat Nuwe-Testamentiese getuienis aangetref. Matteus 27:45-56 berig oor 'n verdrukte ekklēsia wat op grond van die kruisgebeure in Jerusalem bemagtig word en soos in die ko-teks vroeër in Matteus 19:28 gesê is, reeds aan die weergeboorte (palingenesia) deel het. In apokaliptiese/millennialistiese taal word vertel hoe grafte oopgaan en ontslape heiliges Jerusalem ingaan. Die Matteus-Evangelie se oorsprong gaan na alle waarskynlikheid terug na die vroegste ekklēsia wat in Jerusalem tot stand gekom het (Van Aarde, 2002:131; Hengel, 1995:181).

Tekste wat as basis gedien het, kom uit die vroeëre fases van die trajek, soos Esegiël 37:7, 12; 2 Makkabeërs 7, maar ook 1 Henog 51:1-2. In die Makkabeërteks lees ons dat martelare reeds van hulle opstandingsoorwinning verseker is. In die Henog-tradisie verneem ons dat sheol diegene sal teruggee wat aan haar gegee is (vgl. Crossan 1988:392-393). Ander tekste wat kontemporêr is, is dié van Chariton se De Charea et Callirhoe en die Evangelie van Petrus (vgl. Dungan \& Cartlidge, 1974:157-158, 229-233; Price, 2008:5253; Funk, 2008:30-32; Dewey, 2008:61-74).

Deel van die kon-teks van hierdie laaste fase het Jeremias (1985) in sy boek Heiligengräber in Jesu Umwelt uitgewys en dit het reeds vroeg in Israel se gedeelde herinnerings bestaan, naamlik 'n grafkultus. Net soos daar by die graf van Josef by Sigem 'n kultiese beweging soos dié van die Samaritane ontstaan het, en by Betlehem by die graf van Ragel 'n kultus van Messias-volgelinge ontstaan, so ontstaan daar ook 'n kultus rondom die graf van Jesus in Jerusalem. Dit word in Lukas 24 geïllustreer (vgl. veral Prince 2007). ${ }^{19}$ Hier is Christus-volgelinge in beweging vanuit Jerusalem

19 Prince (2007) se studie bevat nie net waardevolle vergelykende tekste vanuit die Grieks-Romeinse konteks nie, maar ook bibliografiese verwysings na ander navorsers se werk oor "kultusse van die dooies". Vergelyk ook Van Tilborg en 
na Jerusalem - van Jerusalem na Emmaus, van Emmaus na Jerusalem. Hulle eet op 'n natuurlike wyse saam met die gekruisigde en opgestane Jesus. Die verwysing na hulle harte wat warm geword het toe hulle Jesus "sien", illustreer hoe 'n gewone staat van bewussyn vinnig in 'n staat van transendente bewussyn oorgaan.

In 326 CE het keiser Konstantyn met die bou van die "grafkerk" (Holy Sepulchre) in Jerusalem begin as 'n herdenking aan Jesus se opstanding. Die kerk is in 335 AE voltooi (vgl. Eusebius, 1955 Vita Constantinii 3.28, in Medieval sourcebook). Volgens MurphyO'Connor (1998:45-47) gaan die vroegste gemeente van Jerusalem se liturgiese byeenkomste by die graf van Jesus terug tot en met die Joodse oorlog in 66 CE. Ons is egter wel bewus dat Konstantyn hierdie bepaalde plek vir die bou van die Jerusalemse basilika gekies het, omdat keiser Hadrianus in $130 \mathrm{CE}$ dáár 'n tempel vir Jupiter opgerig het, nadat hy die Tweede Tempel finaal vernietig en die grond omgeploeg het. Hy het dieselfde met die Samaritane se tempel by Sigem gedoen en dit met 'n tempel vir Zeus vervang. Hoewel 'n mens na alle waarskynlikheid 'n grafkultus by die eerste Jesus-volgelinge in Jerusalem vóór die uitbreek van die Joodse oorlog kan veronderstel, behoort 'n mens ook Aus (2008:161) oor die volgende detail gelyk te gee: "Like the burial site of Israel's first redeemer, Moses, that of Israel's final or great redeemer, the Messiah Jesus, was simply unknown."

Johannes 11:1-44 is op 'n ander manier getuie van dieselfde konteks (vgl. veral Esler \& Piper, 2006). Lasarus sterf op die gewone manier. Hierdie sterwe word met die metafoor slaap beskryf. Die liggaam is reeds aan die vergaan, maar hy lewe weer en dien in die ko-teks as 'n antisipasie wat die leser van Jesus self kan verwag en ook wat die lesers van hulleself kan verwag. Net soos die opgestane Lasarus weer deur die gewone dood bedreig gaan word, word hy ook deur die maghebbers van die tyd bedreig. Net soos Jesus in die Johannes-Evangelie deur Pilatus gedreig en doodgemaak word, en wéér lewe en aan sy volgelinge verskyn en saam met hulle eet, skep Hy vir hulle die geleentheid om tegelykertyd van Bó, van God, gebore te word.

Inkarnasie is om deel van die skepping te word. Reïnkarnasie is om deel van die herskepping te word. Die Johannese gemeente het

Chatelion Counet (2000) se werk oor die "appearances" en "disappearances" in Lukas 24 in vergelyking met kontemporêre tekste uit die Hellenisties-Semitiese leefwêreld. 
hieraan deel gehad, terwyl hulle die ervaring van antagonisme en marginalisasie beleef het.

\section{Persoonlike getuienis}

Vir my is die opstandingsgeloof, na aanleiding van al hierdie getuienisse uit die verlede, steeds 'n kernelement van eksistensiële gelowige te wees. Immers, ek bevind my as deel van die nie-sluitende vyfde skakel: steeds is die konteks van antagonisme en marginalisasie nie afgesluit nie. Op ' $n$ manier is ons steeds deel van 'n grafkultus. Steeds word ons bemagtig, of dit is om op 'n innoverende wyse met moed teologiese en eksegetiese navorsing te doen, en of dit is om as nuwe skepsels aan 'n nuwe Suid-Afrika mee te werk. Die opstandingsgeloof kan steeds vir ons - kollektief gesien of as individuele gelowiges - betekenisvol wees.

Skakels wat nie by hierdie trajek pas nie, is om enige fase in die trajek op 'n historistiese of positivistiese wyse as bruta facta te wil verstaan.20 Die begin van die trajek is die metafoor dat God skep. Die trajek het ontwikkel deurdat daar op 'n konkrete wyse inhoud aan hierdie metafoor gegee is. Israel, martelare, Jesus, Paulus, Matteus, Lukas, Johannes en ook ons is deel van hierdie inhoudgewing. Ook in ons opstandingsgeloof wissel dit tussen 'n metaforiese verstaan en 'n objektiverende verstaan van wat opstanding beteken. Dit is nie 'n óf ... óf nie, maar 'n én ... én.

20 Vir 'n kompakte oorsig van die hedendaagse debat, vergelyk Thiselton (2007:554-565). Onder die verskillende eksponente wat Thiselton bespreek, is dit duidelik dat my eksegetiese geloof minder ooreenkomste het met mense soos Künneth, Pannenberg en Wright, en meer met Bultmann, Conzelmann en Marxsen. Eersgenoemde wil die opstandingsgeloof sien as

\footnotetext{
... a transformative event; but it also [in the words of Pannenberg] 'took place in this world, namely in the tomb of Jesus in Jerusalem before the visit of the women ... Any assertion that an event took place in the past implies an historical claim and exposes itself to testing' (Thiselton, 2007:558).
}

Teenoor die siening dat die opstandingsgeloof gegrond is in die plaasvind van 'n "public event" in die verlede, ontken laasgenoemde teoloë nie

\footnotetext{
$\ldots$ in the very broad sense that a perception of the living Christ has occurred, even if the mode of its perception is allegedly unspecified ... [I]t may signify here no more than an existential perception, without reference to the public world. It implies ... little more than the evoking of faith. [Willi Marxsen] writes: 'The precise nature of the experience' is unclear. The emphasis ... is on present belief, not on a past occurrence (Thiselton, 2007:557-558; kursivering - ACT).
} 
Om in hierdie trajek ' $n$ skakel in te bou dat die credo die krag is waardeur 'n treurende en vresende gelowige hoop sal vind, is om buite die trajek te beweeg. Dit gaan nie om credo's per se nie. Dit gaan om ' $n$ spiritualiteit waarin 'n mens volledig deel van die alledaagse wêreld is en tegelykertyd deel van die transendente is, net soos daar heen en weer tussen metaforiese en objektiverende taal beweeg word.

Gelowiges wat nie self uit hulle dood kan opstaan nie, kan moeilik as nuwe skepsele aan 'n nuwe Suid-Afrika - ofte wel aan die beswil van die wêreldwye omgewing - meewerk. Met Hoover (2008:90) se opmerkings kan ek dus alleen instemming betuig.

Insofar as a resurrection faith expresses a response to the question of whether the pursuit of justice is worth the struggle, whether trying to live responsibly and with integrity is worth the trouble, the resurrection faith of ancient believers is concerned with actual human experience that is continuous with our own, not just with ideas that are dependent upon a no longer credible ancient worldview. What is true may not prevail, but only what is true can enable us to distinguish what is genuine from what is contrived. Justice may not be done, but justice is still the only basis upon which life in a truly human community is possible. Evil may defeat the good, but only the good can nourish and sustain a humane way of life. To affirm such things is to affirm what is continuous with ancient resurrection faith. A resurrection faith has always stood for the justice and moral virtue that are indispensable if human life is to have any final dignity and meaning.

Historici en dogmatici kan die uitnodiging van Lukas in hoofstuk 24 mislees en nie deel kry aan die alternatiewe maaltyd in God se koninkryk wat reeds in hierdie wêreld gevier word nie. Die leë graf is een van die duidelikste illustrasies van hoe creatio ex nihilo telkens weer kan gebeur - of dit nou ook al in die mitiese lewe van Herakles, van Jesus, of van ons was. Vir ons is Jesus, soos Paulus in Filippense 3:9-11, 12-16 skryf, die doel waarheen ons in hierdie trajek op pad is. Herhalend en nogmaals herhalend, so asof die wedloop klaar voltooi is, terwyl die bestemming nog in die toekoms lê. 


\section{Geraadpleegde bronne}

AUER, P. 1996. From context to contextualization. Links and letters, 3:11-28.

AUS, R.D. 2008. The death, burial, and resurrection of Jesus, and translation of Moses in Judaic tradition: studies in Judaism. Lanham: University Press of America.

BALL, A.P. 1902. The satire of Seneca on the apotheosis of Claudius. New York: Columbia University Press.

BARTH, K. 1926. Die Auferstehung der Toten: eine akademische Vorlesung über 1. Kor. 15. 2. Auflage. München: Kaiser.

BECKER, J. 2007. Die Auferstehung Jesu Christi nach dem Neuen Testament. Tübingen: Siebeck.

BERRY, F.M. 1984. An introduction to Stephen C. Pepper's Philosophical system via world hypotheses: a study in evidence. Bulletin of the Psychonomic Society, 22(5):446-448.

BOE, J. 2005. Metaphor, thought, projection and archetype. Psycological perspectives, 48(1):68-83. DOI: 10.1080/00332920591001591.

BOERS, H. 2006. The meaning of Christ's resurrection in Paul. (In Charlesworth, J.H., Elledge, C.D., Crenshaw, J.I., Boers, H. \& Willis, W.W. Resurrection: the origin and future of a Biblical doctrine. New York: Clark. p. 104-138.) (Faith and Scholarship Colloqies.)

BORGEN, P. 1994. "Yes", "no", "how far?": the participation of Jews and Christians in pagan cultures. (In Engberg-Pedersen, T., ed. Paul and his Hellenistic context. Edinburgh: Clark. p. 30-59.)

BULTMANN, R. 1964. Karl Barth: die Auferstehung der Toten. (In Bultmann, R., Hrsg. Glauben und Verstehen. Band 1. 5. Auflage. Tübingen: Mohr. S. 3864.)

CHARLESWORTH, J.H. 2006. Where does the concept of resurrection appear and how do we know that? (In Charlesworth, J.H., Elledge, C.D., Crenshaw, J.I., Boers, H. \& Willis, W.W. Resurrection: the origin and future of a biblical doctrine. New York: Clark. p. 1-21.)

CRENSHAW, J. 1995. The shadow of death in Qohelet. (In Crenshaw, J. Urgent advice and probing questions. Macon: Mercer University Press. p. 573-585.)

CRENSHAW, J. 2006. Love is stronger than death: intimitations of life beyond the grave. (In Charlesworth, J.H., Elledge, C.D., Crenshaw, J.I., Boers, H. \& Willis, W.W. Resurrection: the origin and future of a biblical doctrine. New York: Clark. p. 53-78.)

CROSSAN, J.D. 1988. The cross that spoke: the origins of the passion narrative. San Francisco: Harper \& Row.

CROSSAN, J.D. 2003. The resurrection of Jesus in its Jewish context. Neotestamentica, 37(1):29-57.

DE BOER, M. 1998. The defeat of death: apocalyptic eschatology in 1 Corinthians 15 and Romans 8. Sheffield: Sheffield Academic Press. (Journal for the Study of the New Testament Supplement Series 22.)

DEWEY, A.J. 2008. Resurrection texts in the gospel of Peter. (In Scott, B.B., ed. The resurrection of Jesus: a source book. Santa Rosa: Polebridge. p. 61-74.)

DIODORUS SICULUS. 1 BCE. Diodori Bibliotheca Historica. Vols. 4-5. Ed. by F. Vogel \& K.T. Fischer. Leipzig: Teubner. 
DUNGAN, D.L. \& CARTLIDGE, D.R. 1974. Sourcebook of texts for the comparative study of the Gospels. 4th ed. Missoula: Scholars. (Corrected sources for biblical study 1.)

EDEN, P.T., ed. 1984. Seneca Apocolocyntosis. Cambridge: Cambridge University Press.

ELIADE, M. 1975. Rites and symbols of initiation: the mysteries of birth and rebirth. Trans. by W.R. Trask. New York: Harper \& Row.

ELIADE, M. 1987. De magie van het alledaagse: de transcendentie van het dagelijks leven. Vert. deur H. Andrews. Katwijk: Servire.

ELLEDGE, C.D. 2006. Resurrection of the dead: exploring our earlier evidence today. (In Charlesworth, J.H., Elledge, C.D., Crenshaw, J.I., Boers, H. \& Willis, W.W. Resurrection: the origin and future of a biblical doctrine. New York: Clark. p. 22-52.) (Faith and Scholarship Colloqies.)

ELS, C.W. 2007. Reconciliation in Southern Africa: the role of the Afrikaans churches - a historical and analytical study of the contributions of the Afrikaans churches to the process of reconciliation in Southern Africa, with special reference to their response to the work of the Truth and Reconciliation Commission. Pretoria: University of Pretoria. (Ph.D. dissertation.)

ESLER, P.F. \& PIPER, R. 2006. Lazarus, Mary and Martha: social-scientific approaches to the Gospel of John. Minneapolis: Fortress.

EUSEBIUS PAMPHILI. 1955. Eusebius of Caesare medieval sourcebook: the life of the blessed emperor Constantine. Vol. 1. Ed. by P. Schaff \& H. Wace. Grand Rapids: Eerdmans. (Nicene and Post-Nicene Fathers, 2nd Series.) http://www.fordham.edu/halsall/basis/vita-constantine.html Date of access: 8 Feb. 2010.

FELDMAN, L.H. 1986. How much Hellenism in Jewish Palestine? Hebrew Union College annual (HUCA), 57:83-111.

FELDMAN, L.H. 1997. Hengel's Judaism and Hellenism in retrospect. Journal of biblical literature, 96:371-382.

FUNK, R.W. 2008. The resurrection of Jesus: reports and stories. (In Scott, B.B., ed. The resurrection of Jesus: a source book. Santa Rosa: Polebridge. p. 7-44.)

GRABBE, L.L. 2002. The Jews and Hellenization: Hengel and his critics. Journal for the study of the Old Testament, 340:52-66. (Supplement Series.)

HALLIDAY, M.A.K. 1974. Language and social man. London: Longman.

HALLIDAY, M.A.K. 1985. Language, context, and text. Victoria: Deakin University Press.

HARRINGTON, D.J. 2005. Jesus Ben Sira of Jerusalem: a biblical guide to living wisely. Collegeville: Liturgical Press. (Interfaces.)

HAYES, S.C., HAYES, L.J. \& REESE, W. 1988. Finding the philosophical core: a review of Stephen C. Pepper's world hyopyheses - a study in evidence. Journal of the experimental analysis of behavior, 501:97-111.

HEILER, F. 1961. Erscheinungsformen und Wesen der Religion. Stuttgart: Kohlhammer.

HENGEL, M. 1974. Judaism and Hellenism. 2 vols. London: SCM.

HENGEL, M. 1980. Jews, Greeks and Barbarians: aspects of the hellenization of Judaism in the pre-Christian Period. London: SCM.

HENGEL, M. 1989. The Hellenization of Judea in the first century after Christ. Philadelphia: Trinity. 
HENGEL, M. 1995. "Sit at My right hand!": studies in early Christology. Edinburgh: Clark.

HESIODUS. 1970. Opera et dies. Edited by F. Somsen. Oxford: Clarendon. (Hesiodi Opera.)

HEYNS, J.A. 1978. Dogmatiek. Pretoria: NG Kerkboekhandel.

HONKO, L. 1984. The problem of defining myth. (In Dundes, A., ed. Sacred narrative: readings in the theory of myth. Berkeley: University of California Press. p. 41-52.)

HOOVER, R.W. 2008. Was Jesus' resurrection a historical event? (In Scott, B.B., ed. The resurrection of Jesus: a source book. Santa Rosa: Polebridge. p. 75-92.)

HUMAN, D. 2004. Jona se "opstanding uit die dood": perspektiewe op die opstandingsgeloof vanuit die Ou Testament. Hervormde teologiese studies, 60(1 \& 2):221-238.

JAMES, W. [1902] 1985. The varieties of religious experience. New York: Penguin.

JEREMIAS, J. 1985. Heiligengräber in Jesu Umwelt (Mt. 23, 29; Lk 11,47): eine Untersuchung zur Volksreligion der Zeit Jesu. Göttingen: Vandenhoeck \& Ruprecht.

JOSEFUS. 1955. De bello Judaico: antiquitates Judaicae. (In Niese, B., ed. Flavii losephi opera. Vol. 1. Berlin: Weidman. p. xvii-xviii.)

KANTZER, K. 1958. The Christology of Karl Barth. Bulletin of the Evangelical Theological Society, 1(2):25-28.

KEEL, O. 1972. Die Welt der altorientalischen Bildsymbolik und das Alte Testament. Köln: Benzinger.

LANDES, G.M. 1967. The three days and three nights motif in Jonah 2:1. Journal of biblical literature, 86:446-450.

LIVINGSTONE, D.N. \& HARRISON, R.T. 1981. Meaning through metaphor: analogy as epistemology. Annals of the Association of American Geographers, 71(1):95-107.

MURPHY-O'CONNOR, J. 1998. The Holy Land: an Oxford archaeological guide from earliest times to 1700. 4th ed. revised and expanded. Oxford: Oxford University Press.

NICKELSBURG, G.W.E. 2006. Resurrection, immortality and eternal life in intertestamental Judaism and Early Christianity. Expanded edition. Cambridge: Harvard University Press. (Harvard Theological Studies 56.)

OLDFATHER, C.H. 1935. Diodorus of Sicily, with an English translation. Cambridge: Harvard University Press. (The Loeb Classical Library.)

ORTNER, S.B. 1973. On key symbols. American anthropologist, New series 75(5):1338-1346.

OSIEK, C. 1993. The women at the tomb: what are they doing there? Ex auditu, 9:97-107.

OTZEN, B. 1980. The concept of myth. (In Otzen, B., Gottlieb, H. \& Jeppesen, K. Myths in the Old Testament. London: SCM. p. 1-21.)

PAINTER, J. 2008. The light shines in the darkness ...: creation, incarnation, and resurrection in John. (In Koester, C.R. \& Bieringer, R., eds. The resurrection of Jesus in the Gospel of John. Tübingen: Siebeck. p. 21-46.) (Wissenschaftliche Untersuchung zum Neuen Testament 222.)

PAISLY, I.R.K. 2008. Seven reasons why I believe in the full divinity of Christ. (In Mirus, J.A. The resurrection and divinity of Christ. Evangelical Theological Society. http://www.etsjets.org/ Date of access: 8 Feb. 2007.) 
PEPPER, S. 1935. The root metaphor theory of metaphysics. The journal of philosophy, 32(14):365-374.

PEPPER, S. 1942. World hypotheses: a study in evidence. Berkeley: University of California Press.

PLATO. [1900] 1967a. Phaedo. Ed. by J. Burnett. Oxford: Clarendon Press. (Platonis Opera. Vol. 1.)

PLATO. [1900] 1967b. Leges. Ed. by J. Burnett. Oxford: Clarendon Press. (Platonis Opera. Vol. 5.)

PORTER, S.E., ed. 1997. A handbook to the exegesis of the New Testament: New Testament tools. Leiden: Brill. (Studies and Documents 25.)

PRENTER, R. 1957. Karl Barths Umbilding der traditionellen Zweinaturlehre in lutherischer Beleuchtung: einige vorläufige Beobachtungen zu Karl Barths neuester Darstellung der Christologie. Studia theologia: Nordic journal of theology, 11(1):1-88. DOI: 10.1080/00393385708599778.

PRICE, R.M. 2008. Brand X easters. (In Scott, B.B., ed. The resurrection of Jesus: a source book. Santa Rosa: Polebridge. p. 49-60.)

PRINCE, D.T. 2007. The "Ghost" of Jesus: Luke 24 in light of ancient narratives of postmortem apparitions. Journal for the study of the New Testament, 29(3). Http//jnt.sagepub.com/ogi/content/abstract/29/3/287. DOI: 10.1177/ $0142064 \times 07076309$.

REED, J.T. 1997. Discourse analysis. (In Porter, S.E., ed. Handbook to the exegesis of the New Testament. Leiden: Brill. p. 189-218.)

ROBINSON, J.M. 1971. Introduction: the dismantling and reassembling of the categories of New Testament scholarship. (In Robinson, J.M. \& Koester, $\mathrm{H}$. Trajectories through Early Christianity. Philadelphia: Fortress. p. 1-19.)

ROUKEMA, R. 1998. Gnosis en geloof in het Vroege Christendom. Zoetermeer: Meinema.

ROWLEY, H.H. 1970. Job: the century Bible. Aylesbury: Watson \& Viney. (New series.)

SANDMEL, S. 1962. Parallelomania. Journal of biblical literature, 81:1-13.

SARBIN, T.R. 1986. The narrative as a root metaphor for psychology. (In Sarbin, T.R., ed. Narrative psychology: the storied nature of human conduct. New York: Praeger. p. 3-22.)

SCHÜSSLER FIORENZA, E. 1994. Jesus - Miriam's child, Sophia's Prophet: critical issues in feminist Christology. New York: Continuum.

SCHUTTE, P.J.W. 2008. The origin of the resurrection idea: a dialogue with George Nickelsburg. Hervormde teologiese studies, 64(2):1075-1089.

SIEBERT-HOMMES, J. 2003. Jona. (In Fokkelman, J. \& Weren, W., red. De Bijbel literair: opbouw en gedachtegang van de bijbelse geschriften en hun onderlinge relaties. Zoetermeer: Meinema. p. 279-286.)

SLØK, J. 1960. Sub verbo Mythos. T. 1: Begrifflich und Religionspsychologisch. Religion in Geschichte und Gegenwart, 4.

SNIJDERS, L.A. 1969. Jesaja. Deel 1: De prediking van het Oude Testament. Nijkerk: Callenbach.

STEVEN, R.G. 1933. Plato and the art of his time. The classical quarterly 27(3/4):149-155.

THIESSEN, J. 2009. Die Auferstehung Jesu in der Kontroverse: Hermeneutisch-exegetisch und theologische Überlegungen. Zürich: LIT Verlag.

THISELTON, A.C. 2007. The hermeneutics of doctrine. Grand Rapids: Eerdmans. 
VAN AARDE, A.G. 1997. Side-notes from Graeco-Roman and HellenisticSemitic literature to the notion "adopted as God's child" (huiothesia). Acta Patristica et Byzantina, 8:150-172.

VAN AARDE, A.G. 1998. Dekonstruksie van dogma: 'n eietydse ondersoek na die spore van die leer van die twee nature van Jesus. HTS Teologiese studies, 55(2 \& 3):437-470.

VAN AARDE, A.G. 2000. Jesus and Perseus in Graeco-Roman literature. Acta Patristica et Byzantina, 9:188-201.

VAN AARDE, A.G. 2001. Fatherless in Galilee: Jesus Child of God. Harrisburg: Trinity.

VAN AARDE, A.G. 2002. Matthew and apocalypticism as the "Mother of Christian theology": Ernst Käsemann revisited. HTS Hervormde teologiese studies, 58(1):118-142.

VAN AARDE, A.G. 2004. Skrifbeskouing in die lig van postmoderniteit. HTS Teologiese studies, 60(1 \& 2):503-532.

VAN AARDE, A.G. 2008. Paulus se versie van "draai die ander wang" gedagtes oor geweld en toleransie. HTS Teologiese studies, 64(4):16671697.

VAN DER WALT, T. 1990. Address to the Annual General Meeting of the HSRC Staff Association, 7 May 1990. (In White, C. Can the HSRC join the future? Transformation, 18, 22-34.)

VAN SELMS, A. 1967. Genesis. Deel 1: De prediking van het Oude Testament. Nijkerk: Callenbach.

VAN TILBORG, S. \& CHATELION COUNET, P. 2000. Jesus' appearances and disappearances in Luke 24. Leiden: Brill.

VAN UCHELEN, N. 1971. Psalmen. Deel 1: De prediking van het Oude Testament. Nijkerk: Callenbach.

VERMES, G. 2008. The resurrection: history and myth. London: Penguin.

VERNANT, J.P. 1995. The Greeks. Trans. by C. Lambert \& T.L. Fagan. Chicago: Chicago University Press.

WALSH, R. 2007. The world of Shamanism: new views of ancient traditions. Woodburry: Llewellyn.

WINTER, P. 1974. On the trial of Jesus. Revised and edited by T.A. Burkill \& G. Vermes. 2nd ed. Berlin: De Gruyter.

WRIGHT, N.T. 2003. The resurrection of the Son of God: Christian origins and the question of God. Vol. 3. Minneapolis: Fortress.

WRIGHT, N.T. \& CROSSAN, J.D. 2006. The resurrection: historical event or theological explanation? A dialogue. (In Stewart, R.B., ed. The resurrection of Jesus: John Dominic Crossan and N.T. Wright in dialogue. Minneapolis: Fortress. p. 16-47.)

\section{Kernbegrippe:}

leë graftradisies

opstanding van Jesus

pragmatiese linguïstiek

trajekteorie 


\section{Key concepts:}

empty tomb traditions

pragmatic linguistics

resurrection of Jesus

trajectory theory 
